\title{
VIOLÊNCIA E PROCESSO DEMOCRÁTICO EM HANNAH ARENDT
}

\author{
VIOLENCE AND DEMOCRATIC PROCESS IN HANNAH ARENDT
}

\author{
RENATA ROMOLO BRITO ${ }^{1}$ \\ (Universidade Estadual de Campinas, Brasil)
}

\begin{abstract}
RESUMO
Pretendo mostrar, neste artigo, que a mentalidade alargada arendtiana significa um processo de generalização que não prescinde do contexto, gerando validade sem com isso abrir mão da pluralidade e da particularidade dos participantes, e que é nesse processo que se evidenciam e se realizam os critérios que legitimam as opiniões e a prática política. Em segundo lugar, pretendo mostrar ainda que, a partir dos processos da mentalidade alargada e da definição de normas e critérios legítimos que regulam o espaço público, a filosofia arendtiana contempla a questão da violência justamente ao buscar regras e instituições que visam a conter a violência e a dominação nas relações humanas. A violência, no espaço público arendtiano, tem de ser contida por leis e instituições (quer dizer, pelo Direito), porque ela é um fenômeno desse espaço, e não "externo à polis" e sem relação com o poder. Pretendo, com isso, analisar os estatutos da violência e da opinião em Arendt a fim de compreender o seu conceito de poder como base legitimadora da ação política. A reflexão que aqui desenvolvo tem como fundamento que a política arendtiana se baseia em princípios democráticos de participação ativa que apenas podem se realizar dentro de um quadro institucional organizado juridicamente e que promove a pluralidade humana.
\end{abstract}

Palavras-chave: Mentalidade alargada. Juízo Político. Opinião. Direito. Espaço Público.

\begin{abstract}
I intend to show, in this article, that Arendt's enlarged mentality means a process of generalization that still relies on contexts and generates validity without compromising the plurality and the particularities of its participants, and that it is in this processes the criteria that legitimize opinions and political practices comes to light. Secondly, I intend to show that, out of the processes of the enlarged mentality and the definition of legitimate norms and criteria for the public space, Arendt's philosophy addresses the issue of violence precisely by seeking rules and institutions aiming to curb violence and domination in human relations. Violence, in Arendt's public space, must be restrained by Law and institutions because it's a phenomenon belonging to the public space and not something exterior to the polis and unrelated to power. I intend, in so doing, analyze the concepts of violence and opinion in Arendt in order to understand her concept of power as a legitimizing basis for political action. My reflections are founded on the notion that Arendtian politics is based on democratic principles of active participation that can only take place within an institutional framework legally organized and promoting of human plurality.
\end{abstract}

Keywords: Enlarged mentality. Political Judgment. Opinion. Law. Public Space.

Para Arendt, o pensamento é representativo (ARENDT, 1979, p. 299). Em "Verdade e Política", um dos artigos em que desenvolve essa ideia, Arendt se coloca em uma perspectiva política e não filosófica para questionar a relação entre verdade e política, deixando de lado o problema do estatuto filosófico da verdade (ARENDT, 1979, p. 287). Nesse artigo, ela busca a origem da difícil relação entre verdade e política na oposição entre o pensamento racional do filósofo e o modo de vida do cidadão na polis, traduzindo-se na oposição entre uma única 
verdade eterna e imutável e as várias opiniões constantemente instáveis. A verdade era considerada superior às opiniões justamente porque era eterna e única, e as opiniões eram tidas como simples ilusões em função de sua pluralidade e mutabilidade. Segundo Arendt, essa oposição se manteve, em certa medida, até o século XVIII, porém sofreu uma mudança de ênfase quando a falibilidade da razão foi finalmente reconhecida e a verdade única perdeu seu status superior. Para ela, tanto o reconhecimento das limitações de razão, na Crítica da Razão Pura de Kant, quanto as afirmações de Madison de que "todo governo assenta-se na opinião" (ARENDT, 1979, p. 289) ou de que "a razão do homem, como o próprio homem, é tímida e cautelosa quando a sós, e adquire firmeza e confiança em proporção ao número dos que se lhe associam" (ARENDT, 1979, p. 290-1) ${ }^{2}$ demonstram uma valorização do estatuto da opinião em relação à verdade. Porque a razão é falível, não se pode mais pensar em termos de uma única verdade, e o que resta ao homem é comunicar seus pensamentos aos demais publicamente. É assim que Arendt relaciona a opinião ao espaço público.

O uso público da razão, a comunicação da opinião aos demais por meio do discurso, é, para Arendt, consequência da condição humana da pluralidade. Os homens existem no plural, e até mesmo no pensamento essa pluralidade está presente. O conceito tradicional da verdade filosófica implica um modo de vida não-político porque se dá no isolamento, enquanto que a pluralidade das opiniões no espaço público reflete a pluralidade da existência humana. A valorização da opinião significa a própria valorização do âmbito político. Arendt afirma:

O deslocamento da verdade racional para a opinião implica uma mudança do homem no singular para os homens no plural, e isso significa um desvio de um domínio em que, diz Madison, nada conta a não ser o raciocínio sólido de uma mente para uma esfera onde a força da opinião é determinada pela confiança do indivíduo no número dos que ele supõe que nutram as mesmas opiniões - um número, aliás, que não é necessariamente limitado ao dos seus contemporâneos. (ARENDT, 1979, p. 292).

É nesse sentido que Arendt afirma que o pensamento político é representativo. Uma opinião é formada ao considerar-se uma questão sob diferentes perspectivas, isto é, ao se representar para a mente as perspectivas daqueles que não estão lá. Isso não significa trocar seu próprio ponto de vista por pontos de vista alheios, ou se igualar com o outro ou mesmo se juntar à maioria, mas:

ser e pensar em minha própria identidade onde efetivamente não me encontro. Quanto mais posições de pessoas eu tiver presente em minha mente ao ponderar um dado problema, e quanto melhor puder imaginar como eu me sentiria e pensaria se estivesse em seu lugar, mais forte será minha capacidade de pensamento 
representativo e mais válidas minhas conclusões finais, minha opinião. (ARENDT, 1979, p. 299).

A capacidade de realizar essa representação de diferentes pontos de vista para, em seu próprio lugar, pensar e chegar a uma conclusão é o que Arendt chama de mentalidade alargada, capacidade que teria sido descoberta por Kant na Crítica do Juízo ${ }^{3}$. Para Arendt, arte e política são fenômenos intrinsecamente ligados porque ambos são fenômenos do mundo público (ARENDT, 1979, p. 272), ambos envolvem um cuidado com esse mundo e dizem respeito à aparência do mundo para aqueles que o dividem. Dado esse elemento comum entre a arte e a política - ambos relacionam-se a uma comunidade de espectadores, seja uma comunidade de espectadores da beleza ou uma comunidade de homens de ação ${ }^{4}$ - o juízo político arendtiano se baseia no juízo estético kantiano porque, segundo ela, é nesse momento que Kant insiste em uma forma diferente de se pensar (ARENDT, 1979, p. 274), levando em conta a própria comunidade e não a razão transcendental de um homem isolado.

Para Arendt, na Crítica do Juízo, Kant não se baseia mais na razão de um homem isolado e na harmonia interna de seu pensamento; ao contrário, a validade e a força de um juízo se assentam em um acordo potencial com os outros e na capacidade de se pensar no lugar de outrem (ARENDT, 1979, p. 274). É essa antecipada comunicação com os outros, esse acordo potencial, o que dá uma validade específica para o juízo.

Um dos principais pressupostos arendtianos em relação ao juízo é que a capacidade de julgar é uma capacidade distinta das demais capacidades da mente humana, porque o juízo não é realizado de acordo com o princípios de dedução e indução e, em última análise, não possui nada em comum com essas operações lógicas. O juízo lida com particulares. A mente, ao lidar com universais ou generalidades, necessita de uma faculdade distinta ao se voltar ao mundo e encontrar apenas particularidades (ARENDT, 2002, p. 162). Essa faculdade, no campo da estética, tradicionalmente foi considerada como o "gosto", e no campo da política e da moral, "consciência", embora sejam a mesma faculdade. No campo estético, essa faculdade foi continuamente exercitada pelos homens, que emitem juízos, porém no campo da política e da moral, a "consciência" sempre foi relacionada a uma fonte de autoridade externa e superior que determinava o que fazer e do que se abster, e portanto se calava (ARENDT, 2002, p. 162). Não obstante, quando não há mais uma autoridade que indique qual a regra a se seguir, só restam aos homens as particularidades e as contingências dos assuntos humanos, e apenas a faculdade do juízo - a sua capacidade de emitir juízos e encontrar critérios a partir de particulares - é que pode orientá-los. Desse modo, Arendt não tem problema algum em 
analisar o juízo político e o juízo moral conjuntamente com o juízo estético, porque são juízos emitidos pela mesma faculdade mental e, também em função disso, dizem respeito a fenômenos intrinsecamente ligados, como dito acima. Creio ser importante enfatizar também que o homem de ação, como aquele que participa do mundo e para quem o mundo aparece, é aquele que sempre tem uma perspectiva em relação a esse mundo comum; ele é sempre, concomitantemente, um espectador. Os momentos em que há uma primazia do pensamento e da reflexão e os momentos em que há uma primazia do agir se alternam, porém não são excludentes. O homem que age também é um espectador, não porque ele está fora do espaço público observando de longe a performance do agente, mas porque ele é um integrante do espaço público cuja qualidade essencial é especificamente a de ser composto por perspectivas 5 .

Arendt se baseia, então, no juízo estético kantiano como modelo para o juízo político porque ele é reflexionante e não funciona de acordo com a subsunção de particulares a normas universais. Como não existe uma regra universal que defina o que é ou não belo, o que permite o juízo estético - orientando o juízo e, nesse sentido, ocupando o lugar da norma universal na estrutura do julgar - é a faculdade do gosto. É o gosto, referindo-se à comunidade em que o juízo é realizado, que gera o critério para o juízo. O gosto é, nesse sentido, um sensus communis, e significa, fundamentalmente, a capacidade de julgar de acordo com os valores, as referências e os padrões que são compartilhados e construídos, com o próprio exercício do juízo, por determinada comunidade. O gosto é, então, a faculdade judicante que todos os homens possuem e podem exercitar. Ele orienta a criação da obra pelo gênio, dando-lhe clareza, ordem e, principalmente, comunicabilidade. Apenas quando algo é comunicável é que ele passa a ser relevante em uma comunidade, porque a comunicabilidade permite que os integrantes possam entender, acompanhar, discernir e discriminar aquilo que vêem, o que significa que eles podem realizar um juízo sobre esse algo e se posicionar diante dele (ARENDT, 1994b, p. 80-1). A referência desse juízo é a comunidade em que esse juízo é realizado, e não uma regra universal. Assim, a análise kantiana do gosto proporciona a Arendt as noções de comunicação, intersubjetividade, acordo intersubjetivo e juízo compartilhado que norteiam a sua política.

Julgar depende, de certa forma, de uma abstração. O juízo não é o mesmo que a percepção, pois a percepção é privada e uma reação imediata ao objeto. Já o juízo ocorre na ausência do objeto, é uma atividade mental, uma reflexão, que se baseia em uma representação do objeto à mente. $\mathrm{O}$ juízo não se confunde com uma reação sensorial ou com 
uma preferência pessoal porque a representação gera um distanciamento entre a mente e o objeto. E quem realiza essa representação é a faculdade da imaginação. Quando o objeto não está mais presente, o homem pode percebê-lo de uma nova forma, não mais com seu aparato sensorial, mas apenas com a mente, que agora passa a refletir sobre o objeto. É essa reflexão que é comunicável, e não as sensações privadas do indivíduo.

A imparcialidade provém de não se estar diretamente afetado pelo objeto (ARENDT, 1994b, p. 86). Sem essa afecção, a mente, como um sentido interno, experimenta novamente o objeto e pode emitir juízos não apenas sobre se o objeto agrada ou não, mas também emite um segundo juízo sobre a reação da mente em relação ao objeto. Nas palavras de Arendt:

\begin{abstract}
A operação da imaginação tornou o que está ausente imediatamente presente ao sentido interno, discriminador por definição - ele diz 'isso me agrada ou desagrada'. É chamado gosto porque, como o gosto, ele escolhe. Mas a própria escolha está sujeita a uma outra escolha: podemos aprovar ou desaprovar o próprio fato do agradar: isso também está sujeito à 'aprovação ou desaprovação'. (...) O próprio ato de aprovar agrada, o próprio ato de desaprovar desagrada. E daí a questão: como escolher entre a aprovação e a desaprovação? (ARENDT, 1994b, p. 88-9).
\end{abstract}

A aprovação do ato de aprovar é chamada por Arendt de um pensamento posterior; essa aprovação é um juízo do que é ou não agradável e não mais uma reflexão sobre um objeto. E o critério para julgar o que é ou não agradável também não vem do objeto, mas estabelece-se em referência aos valores e padrões que são partilhados pela comunidade. Os juízos são realizados tendo como referência um possível acordo com o outro, e porque o poder do juízo depende de um acordo, ele é persuasivo: "nunca podemos forçar ninguém a concordar com nossos juízos (...); podemos apenas 'cortejar' ou 'pretender' a concordância dos outros". O critério da validade do juízo está, em vista disso, na sua comunicabilidade e na sua publicidade, e a regra para sua decisão é o senso comum (ARENDT, 1994b, p. 89). A comunicação entre os homens estabelece algo como uma ponte entre os sujeitos que julgam, e é dessa forma que se constrói um senso comum, uma comunidade de acordos e juízos compartilhados.

Como Arendt sempre repete: julgamos como membros de uma comunidade. No juízo, é possível "alargar" o pensamento para levar em consideração o juízo dos outros, e isso é realizado com a comparação de seu próprio juízo com os possíveis juízos alheios, e por colocar-se no lugar dos outros. "Pensar com a mentalidade alargada significa treinar a própria imaginação para sair em visita" (ARENDT, 1994b, p. 57), quer dizer, é representar à mente as perspectivas alheias. Quanto mais perspectivas são representadas em um juízo, mais imparcial 
ele é: “(...) a imparcialidade é obtida por meio da consideração dos pontos de vista dos outros; a imparcialidade não é resultado de um ponto de vista mais elevado, que pudesse resolver a disputa por estar acima da confusão" (ARENDT, 1994b, p. 56). Trata-se, desse modo, de um ponto de vista geral que é válido para uma determinada comunidade porque foi construído a partir das perspectivas de seus integrantes, e quanto maior generalidade, mais validade ele terá naquela comunidade. Aqui reside a especificidade política da faculdade de julgar:

o juízo é dotado de certa validade específica, mas não é nunca universalmente válido. Suas pretensões a validade nunca se podem estender além dos outros em cujo lugar a pessoa que julga colocou-se para suas considerações (ARENDT, 1979, p. 275).

A validade desses juízos não é nem objetiva e universal, nem meramente subjetiva (isto é, dependente de caprichos particulares), mas intersubjetiva e representativa (ARENDT, 2010a). De fato, poder é agir em comum acordo, e esses acordos só se mantêm com consentimento, quer dizer, com a opinião de que esses acordos são legítimos ${ }^{6}$. E o que fundamenta uma opinião, dando-lhe validade e dignidade, é o juízo ${ }^{7}$. Isso significa que, porque se baseia na faculdade de julgar, a opinião, para Arendt, mantém uma respeitabilidade e é dotada de validade - uma validade que difere da validade universal tradicional, porém que tem maior importância política porque está de acordo com a existência plural dos homens. Trata-se, portanto, de uma validade intersubjetiva, porque construída em processos comunicativos de uma comunidade específica, e de uma validade geral, porque engloba todos os envolvidos daquela comunidade, sem aspirar a uma universalidade para todos os seres racionais ou todas as pessoas capazes de discurso. Aqui Arendt textualmente se afasta de Kant, defendendo um ponto de vista geral e não universal como fundamento de juízos morais ou políticos válidos, dado que um ponto de vista universal aos moldes kantianos tradicionais impede a pluralidade de opiniões e perspectivas no espaço público (tal é sua crítica ao conceito tradicional de verdade filosófica).

O que eu gostaria de enfatizar é que, para Arendt, o cerne da questão é a formação intersubjetiva do ponto de vista "geral", que parte do contexto e se relaciona a esse contexto, porém adquire imparcialidade e legitimidade. Não se trata aqui de um relativismo, visto que existem princípios que guiam a construção desse ponto de vista, caso contrário não seria possível chegar a uma imparcialidade. Contextualismo não significa o mesmo que relativismo, porque, embora não prescinda do contexto, ele é capaz de fornecer critérios que orientam a 
ação humana em qualquer circunstância. Gostaria de sugerir que o princípio que, em última análise, guia a formação desse ponto de vista imparcial e legítimo é a pluralidade humana (ARENDT, 2003). A mentalidade alargada arendtiana é um processo que contempla a pluralidade de perspectivas e opiniões inerente às relações dos homens, possibilitando a política e a ação. Em $A$ Condição Humana, Arendt defende que a existência humana se dá de uma forma plural, o que significa que os homens são sempre distintos entre si, embora todos sejam humanos, e é por causa dessa pluralidade que os homens se relacionam por meio do discurso e são capazes de agir livremente.

Por serem distintos, os homens possuem perspectivas diferentes, e apenas em interações discursivas é que podem se entender. Em outras palavras, a mentalidade alargada é o que permite a comunicação, o discurso da ação humana. O que significa que o processo da mentalidade alargada é característico da ação humana. A capacidade humana de agir significa a capacidade de iniciar novos processos espontâneos (ARENDT, 2003, p. 243), o que Arendt chama de "caráter processual da ação" ${ }^{8}$. Como o agente sempre se encontra entre outros agentes, isto é, na teia de relações, cada ação gera novas ações, o que significa que os homens agem em um meio em que cada reação se torna uma reação em cadeia, e cada processo é a causa de novos processos. A ação é sempre ilimitada porque suas conseqüências se desenvolvem de forma potencialmente infinita (ARENDT, 2003, p. 203). Essa natureza processual da ação se traduz em um espaço público em que o debate é sempre contínuo e permanente, visto que cada opinião e cada posição geram novas opiniões e novos juízos ininterruptamente. O acordo é, em função disso, provisório, porque sempre pode ser questionado, um vez que é próprio de cada processo ser marcado pela incerteza. Em última análise, esse processo é a manifestação da pluralidade humana, que é atualizada em cada ação.

É nesse sentido que a ação, ou poder, pode ser compreendido como um "fim em si mesmo" (ARENDT, 2003, p. 218). O poder serve para manter a prática do poder, consolidando-se em instituições que asseguram a prática comunicativa. Sua normatividade implica a necessidade de manutenção de práticas discursivas (e de instituições que asseguram essas práticas) e na proibição de restrições a essa prática. Em outras palavras, trata-se aqui de um processo democrático. É importante salientar que o caminho encontrado por Arendt com a noção de mentalidade alargada não está dissociado de sua inspiração aristotélica contextualista, mas, ao contrário, o conteúdo normativo do conceito de poder se mantém justamente porque permanece vinculado às práticas políticas democráticas. Afirmar que o poder serve para manter práticas de geração de poder implica questionar as condições para a 
continuidade e a manutenção do processo discursivo, quer dizer, da prática democrática, colocando esse próprio processo em pauta de discussão, pois apenas assim é possível assegurar-se de sua contínua legitimidade ${ }^{9}$.

Entretanto, essa noção de ação como processo e a normatividade do conceito de poder arendtiano que se baseia no discurso só podem ser compreendidos dentro de uma estrutura institucional, porque a comunicação e o discurso só são possíveis em um espaço estruturado que garanta a liberdade dos homens para agir e se comunicar. Essa liberdade é garantida na medida em que a violência é contida, pois a violência é a forma pela qual um homem domina e submete o outro, impedindo-o de agir. Quando há violência, as relações não são entre agentes que se comunicam de forma livre e igual, mas são de domínio e submissão, de comando e obediência. E a violência não se restringe apenas à coerção física, mas significa qualquer meio que destitua um homem de liberdade.

Em um debate acerca da legitimação da violência (ARENDT, 2010b), Arendt afirmou que o oposto da liberdade é ou a necessidade ou a opressão. A partir daí, ela distingue três formas tradicionais de justificar a violência e critica a tendência, na história do pensamento político, de valorizar a ideia de violência no espaço público como se ela fosse necessária e criativa, isto é, como se ela trouxesse à tona ou transformasse a sociedade, posição de que Arendt discorda profundamente.

A primeira justificação teórica da violência que Arendt critica é a de Marx, que pensa a violência como inevitável à política. Segundo ela, desde que Marx comparou a revolução ao nascimento de uma nova sociedade e a violência com as dores do parto, isto é, que a velha sociedade estaria "grávida" de uma nova e teria a violência como parteira, a violência foi tida como natural e, portanto, inescapável. Isso está de acordo com a noção de História como um processo natural, que se baseia no metabolismo biológico do homem com a natureza ${ }^{10}$. Já a segunda justificação teórica é melhor representada, de acordo com Arendt, por George Sorel, que acreditava que a violência é essencialmente criativa. O que está por trás dessa crença é a experiência da fabricação e a noção de que há um elemento de violência em toda criação, visto que é preciso destruir algo - pelo menos a matéria prima -- para obter-se um produto final ${ }^{11}$. A terceira justificativa, aponta Arendt, é mais recente e apareceu na introdução de Sartre ao livro Os Condenados da Terra, de Frantz Fanon, em que Sartre defenderia uma violência que não é nem som nem fúria, nem a ressurreição dos instintos selvagens, nem sequer ato de ressentimento: é o homem recriando a si mesmo, em um passo para além de Marx, em que a violência é a criadora do homem ${ }^{12}$. 
Arendt lida com essas três justificações para a violência ao distinguir três esferas distintas da existência humana, mais notavelmente em $A$ Condição Humana. A noção de condição humana do trabalho, que responde às necessidades da vida biológica, aparece como uma resposta à justificativa marxista de que a violência é natural e inevitável. Ao se tratar de seu próprio metabolismo com a natureza e de sua sobrevivência biológica, o homem está sujeito às necessidades imperiosas da natureza e não possui escolha sobre isso. As necessidades biológicas devem ser atendidas e isso é, de fato, inevitável. Nesse sentido, no "ciclo da vida" existe realmente uma violência natural a que o homem está sujeito, quer dizer, uma necessidade obrigatória que não deixa espaço para a liberdade, uma força que compele, constrange e obriga. Em resposta a isso, o homem trabalha, forçosamente. Entretanto, para Arendt, não é a atividade do trabalho que cria a política, quer dizer, não é porque também pertencemos ao grande ciclo da vida orgânica que nós somos seres políticos (ARENDT, 2010b). Isso significa que a necessidade natural não é um modelo para a violência que ocorre nas relações entre os homens, quer dizer, devido à organização política. Necessidade e opressão não são o mesmo, e a metáfora marxista induz ao erro. Em Sobre a Revolução, Arendt critica Marx por essa equiparação, que acaba por mascarar a artificialidade da violência:

\begin{abstract}
Uma vez estabelecida uma relação concretamente existente entre violência e necessidade, não havia razão para não pensar a violência em termos de necessidade e entender a opressão como resultado de fatores econômicos, muito embora, originalmente, essa relação tivesse sido descoberta ao inverso, isto é, desmascarando a necessidade como violência perpetrada pelos homens. Essa interpretação deve ter exercido forte apelo a seu senso teórico, pois a redução da violência à necessidade oferece a inegável vantagem teórica de ser muito mais elegante; ela simplifica as questões a ponto de tornar supérflua uma efetiva distinção entre violência e necessidade. Pois, de fato, é muito fácil entender a violência como função ou fenômeno de superfície de uma necessidade subjacente avassaladora, mas a necessidade, que inevitavelmente trazemos conosco na própria existência de nosso corpo e suas demandas, nunca pode ser simplesmente reduzida e completamente absorvida pela violência e pela violação. Foi o cientista em Marx e a ambição de elevar sua 'ciência' ao nível de ciência natural, cuja principal categoria naquela época ainda era a necessidade, que o levaram a inverter suas próprias categorias. Politicamente, esse desenvolvimento o levou a uma rendição efetiva da liberdade à necessidade. (ARENDT, 2011, p. 98-9).
\end{abstract}

Não se trata aqui de negar que a necessidade não seja um obstáculo à liberdade, e que fatores econômicos não possam ser opressivos, mas de estabelecer uma distinção entre necessidade e opressão, entre a necessidade natural e a violência artificial - que é criada pelo homem -, e que recaem sobre os seres humanos em âmbitos distintos. A necessidade como 
uma força natural a que o homem está sujeito ocorre de forma diferente da opressão e da tirania ${ }^{13}$. A sujeição de um homem a outro homem não é determinada e necessária como o é a sujeição do homem aos impérios da natureza, e a distinção arendtiana entre trabalho e ação espelha essa diferença: enquanto o trabalho é inevitável - todo homem precisa do trabalho (seu ou de outrem) para manter-se vivo -, a ação é livre e modelada pelas relações entre os indivíduos, ocorrendo em um espaço que não é predeterminado e não é necessariamente violento. A crítica de Arendt à vitória do animal laborans na modernidade visa a revelar uma organização institucional moderna que elimina o espaço próprio da política, que precisa ser recuperado. O trabalho, como condição humana, é um fato da existência que o homem não pode mudar. Em contrapartida a isso, o homem constrói um mundo artificial em que pode agir, e agindo, formar corpos políticos propriamente ditos. Da natureza não emerge política, da necessidade não emerge liberdade. A política, para Arendt, é artificial, é criada pelos homens, dependente da ação e da organização humana. Da mesma forma, a violência no espaço político é artificial, porque significa dominação de um homem sobre o outro, e não significa o mesmo que a violência natural e necessária a que o animal laborans está sujeito. No entanto, a naturalização do paradigma da violência torna-a especialmente ubíqua e necessária.

O mais importante a se reter dessa diferença é justamente que a ação política não é intrinsecamente violenta, pois se a necessidade significa que aquilo que é não poderia ser de outra forma, a liberdade significa justamente que aquilo que é pode também ocorrer de outra maneira.

O principal problema da equiparação entre poder e violência, entre poder e dominação, é a crença de que a política é necessariamente violenta, e apenas com mais violência é que é possível conter a dominação - isso porque, claro, a mais plausível justificação da violência é que apenas mais violência pode responder à violência. Isso se junta à noção de que a violência é essencialmente criativa, e que, em uma sociedade de produtores, a filosofia máxima seria uma filosofia da violência, que criaria uma nova sociedade por seu próprio desígnio. Ao tratar da condição humana da fabricação, Arendt reconhece esse elemento criativo da violência, visto que para construir um novo objeto é preciso a destruição de algo anterior - nunca a criação é uma criação a partir do nada. Mas, embora ela possua realmente um elemento criativo, essa violência só se justifica dentro de um processo limitado de fabricação, regido pela lógica da instrumentalidade. A utilidade, princípio máximo da fabricação, é capaz de determinar os melhores meios para se atingir um determinado fim, mas nunca é capaz de legitimar esses fins. A violência, sendo um instrumento, é possível de ser justificada pelos 
fins que atinge, e quando se trata da atividade da fabricação, temos sempre um fim palpável que justifica os meios. Arendt, todavia, salienta que esse não é o caso com a ação política. No âmbito político, a violência perde sua criatividade junto com seu caráter instrumental porque nada nesse âmbito é alcançado que possa ser sequer assemelhado ao produto final da fabricação (ARENDT, 2010b). A violência criativa do homo faber não pode ser transposta para o âmbito da política, visto que a lógica da relação meio-fim não pode ser aplicada à teia de relações. Em Da Violência, Arendt é enfática ao afirmar que:

\begin{abstract}
A violência, sendo instrumental por natureza, é racional na medida em que for eficaz para alcançar o fim que a deve justificar. E uma vez que quando agimos nunca sabemos exatamente as conseqüências eventuais daquilo que estamos fazendo, a violência só pode ser racional se persegue objetivos a curto prazo. A violência não estimula causas, nem história nem revolução, nem progresso nem reação; mas serve para dramatizar ressentimentos e trazê-los ao conhecimento do público. (...) E na verdade, a violência, contrariamente ao que seus profetas nos tentam impingir, é mais a arma da reforma que da revolução. (ARENDT, 2006, p. 140-50).
\end{abstract}

Dessa forma, mesmo podendo ser justificada por objetivos imediatos, a violência não é aquilo que legitima e dá significado a uma comunidade política como um todo. Como algo que precisa ser justificado, ela não pode, por si mesma, justificar ou legitimar nada. A legitimação da comunidade política é dada por meio da comunicação e do consentimento. Nesse sentido, Arendt afirma:

\begin{abstract}
(...) o poder é da essência de todos os governos, mas a violência não. A violência é por natureza instrumental; como todos os meios, sempre necessita de orientação e justificação pelos fins que persegue. E o que necessita ser justificado por alguma outra coisa não pode ser a essência de coisa alguma. (...) (Isso, evidentemente, não significa negar que os governos busquem determinadas políticas e empreguem seu poder para alcançar objetivos determinados. Mas a estrutura do poder por si própria precede e perdura além de todos os objetivos, de maneira que o poder, longe de ser o meio para a consecução de um fim, é realmente a própria condição que possibilita a um grupo de pessoas pensar e agir em termos da categoria de meios e fim.) (ARENDT, 2006, p. 128-9, tradução modificada).
\end{abstract}

Arendt, assim, defende que a violência em um governo constitucional é um fenômeno marginal, uma salvaguarda do poder, justificado na medida em que é usado para manter a estrutura de poder intacta, defender os cidadãos contra crimes ou contra um agressor externo (ARENDT, 2010b e ARENDT, 2006). A resposta ao criminoso que viola a lei é a violência, mas trata-se de uma violência limitada, instituída pela lei e legítima dado o quadro institucional de que faz parte. 
Por fim, Arendt recusa completamente a última justificativa teórica para a violência a noção de Sartre de que a violência cria o próprio homem. Em Origens do Totalitarismo, Arendt aponta que a noção de que a violência pode recriar o homem é justamente a esperança que guia os governos totalitários ao tentar aplicar a lei da Natureza ou a lei da História diretamente sobre os homens, numa tentativa de engendrar a humanidade como um produto final (ARENDT, 1989b, p. 514). Todavia, ela mostra que, exatamente ao contrário do que quer Sartre, a violência absoluta no espaço político destruiu os homens, física e psicologicamente, aniquilando a própria possibilidade de se criar algo novo, justamente porque tenta destruir a capacidade humana de agir (ARENDT, 1989b, p. 517). O totalitarismo ataca a própria condição humana da natalidade, visando a eliminar as relações humanas como um todo:

\begin{abstract}
Em lugar das fronteiras e dos canais de comunicação entre os homens individuais, [o terror total] constrói um cinturão de ferro que os cinge de tal forma que é como se a sua pluralidade se dissolvesse em Um-Só-Homem de dimensões gigantescas. Abolir as cercas da lei entre os homens - como o faz a tirania - significa tirar dos homens os seus direitos e destruir a liberdade como realidade política viva; pois o espaço entre os homens, delimitado pelas leis, é o espaço vital da liberdade. O terror total usa esse velho instrumento da tirania mas, ao mesmo tempo, destrói também o deserto sem cercas e sem lei, deserto da suspeita e do medo que a tirania deixa atrás de si. Esse deserto da tirania certamente já não é o espaço vital da liberdade, mas ainda deixa margem aos movimentos medrosos e cheios de suspeita dos seus habitantes.

Pressionando os homens, uns contra os outros, o terror total destrói o espaço entre eles; comparado às condições que prevalecem dentro do cinturão de ferro, até mesmo o deserto da tirania, por ainda constituir algum tipo de espaço, parece uma garantia de liberdade. $\mathrm{O}$ governo totalitário não restringe simplesmente os direitos nem simplesmente suprime as liberdades essenciais; tampouco, pelo menos ao que saibamos, consegue erradicar do coração dos homens o amor à liberdade, que é simplesmente a capacidade de mover-se, a qual não pode existir sem espaço. (ARENDT, 1989b, p. 518).
\end{abstract}

Mesmo reconhecendo a atração que o ato violento ou mesmo a guerra pode ter (Arendt descreve, no prefácio ao livro The Warriors, de Glenn Gray, que a violência pode gerar uma sensação de êxtase de certa forma fascinante que chega até a criar um laço entre os perpetradores), Arendt insiste que a violência é sempre um meio para algum fim e não pode substituir todas as qualidades políticas da capacidade humana de agir. Pela ação, o homem revela quem ele é aos demais; estabelece laços de igualdade com outros homens; forma uma teia de relacionamentos e memória em que a história humana é escrita; cria espaços de publicidade e debate; organiza esses espaços; busca, reflete e mantém o significado de suas ações - e tudo isso só é possível por meios discursivos. A violência entre os homens é sempre 
opressão. Onde há violência, não há espaço para a liberdade e a palavra. A violência é muda (ARENDT, 2003 e ARENDT, 1994b), e é por isso que a ela não pode, nunca, substituir o poder.

O poder é a essência de todos os governos, mas a violência não. E a função da distinção arendtiana entre poder e violência é negar a equiparação entre poder, por um lado, e violência, vida e criatividade, por outro. Apenas quando tomada como diferente do poder, mas ainda como um fenômeno próprio do espaço político, um fenômeno criado pelos próprios homens e dependente da organização humana, é que é possível lidar corretamente com a violência ${ }^{14}$. É preciso compreender as limitações que a violência possui, e o que ela pode ou não fazer no espaço público. Segundo Arendt, ao contrário do poder, a violência não precisa de pessoas, ela pode existir na forma extrema de um contra todos, e quando ela reina absoluta, não há espaço para o poder. Se não for devidamente controlada, a violência pode destruir completamente o próprio espaço político em que o poder aparece; no entanto, é o poder que pode controlar e corrigir esse instrumento. Arendt está bastante ciente de sua quebra com a tradição ao definir o poder como agir em conjunto. É importante lembrar que, em $D a$ Violência, Arendt introduz a definição de poder em contraposição à perspectiva tradicional de que poder e violência são fenômenos indistintos, o que reflete a convicção subjacente de que a questão de "quem domina quem" é a questão política fundamental (ARENDT, 2006, p. 122) 15. É primeiramente contra essa identificação entre poder e dominação que Arendt constrói seu conceito, definindo poder como liberdade, e violência (na política) como dominação. Enquanto fenômenos isolados, força, vigor e violência são de fato assemelhados e, dependendo da forma como aparecem no mundo humano, podem ser justificados ${ }^{16}$. Mas a dominação e a subjugação de um homem pelo outro, não importa por qual meio, é sempre ilegítima, porque destrói o equilíbrio necessário para uma relação entre iguais. Nesse sentido, onde há dominação não há poder.

O Direito aparece, então, na obra arendtiana, como um dos meio de conter e limitar a violência. A análise arendtiana ao fim de Origens do Totalitarismo mostra que o primeiro obstáculo contra a dominação - ou a violência - é o Direito. Segundo Arendt: “O primeiro passo essencial no caminho do domínio total é matar a pessoa jurídica do homem." (ARENDT, 1989b, p. 498), porque o Direito funciona como uma capa protetora contra a violência, assegurando a liberdade dos homens.

Isso é possível porque a liberdade só existe entre iguais. Sem igualdade, isto é, onde há domínio e violência, não é possível haver discurso, que presume uma participação e um 
reconhecimento de todos como parceiros ou como seus pares. E como os homens não são naturalmente iguais, essa igualdade precisa ser construída por eles artificialmente, de forma a equalizar constantemente suas diferenças. Essa equalização é realizada por meio do Direito, isto é, pela atribuição de direitos iguais. Igualdade para Arendt é “um princípio operacional da organização política, segundo o qual pessoas desiguais têm iguais direitos" (ARENDT, 1989b, p. 76). A igualdade política é, e só pode ser, uma igualdade jurídica, cujo sentido significa a ausência da dominação de um homem pelo outro. Em suma, a igualdade, essencial para o espaço público legítimo, é criada através do Direito.

Direitos são atribuídos às pessoas com a criação de uma personalidade jurídica, que é a forma de investir alguém de direitos e estabelecer uma posição reconhecível para os homens dentro do corpo jurídico. O Direito erige, dessa forma, fronteiras e limites para cada participante da comunidade política, ao mesmo tempo que permite que eles se relacionem. Graças à personalidade jurídica, homens diferentes podem se relacionar como iguais, e quando essa igualdade sofre algum ataque, isto é, quando a violência substitui o discurso, é função do direito restaurar a legitimidade das relações políticas. Dessa forma, é função do Direito conter a violência, organizando o espaço público ao lhe dar a estrutura institucional necessária para seu funcionamento legítimo.

Como a igualdade jurídica significa ausência de dominação nas relações políticas, isto é, significa que cada cidadão precisa ter uma posição reconhecida e equivalente no corpo político, a violência não se restringe apenas à coerção física, mas importa em qualquer meio de submissão de um homem pelo outro. Por isso, a coerção moral, a manipulação de informações, o bloqueio de comunicações que servem de base para determinadas convicções legitimadoras do espaço público, tudo isso são também formas violentas de dominação, cuja contenção é também papel do Direito ${ }^{17}$. Caso contrário, não é possível falar-se de um espaço público legítimo.

Arendt não ignora o fenômeno da violência e, principalmente, não o trata como se a violência não fizesse parte do espaço público. A distinção arendtiana entre poder e violência é um distinção analítica, que visa a compreender os fenômenos da coerção e do poder que coexistem no mesmo espaço e que, por isso, precisam de instituições humanas para organizá-los de modo a manter a legitimidade desse mesmo espaço. Essa é a razão de ser do Direito. Arendt está ciente de que a violência é constante nas relações humanas e que as relações políticas são permeadas por violência, e esse é o motivo de ela enfatizar a necessidade de uma 
organização institucional do espaço público capaz de criar e manter uma igualdade, sempre ameaçada.

Em outras palavras, o fenômeno da violência pertence ao mundo humano, e apenas com instituições criadas para conter e limitar esse fenômeno é que se organiza o espaço público. Essa organização se dá pela ação, que é a capacidade política do ser humano, e se estabelece por meio do Direito. A igualdade política, isto é, a igualdade de direitos, princípio organizacional básico da política arendtiana que garante a participação de todos, significa especificamente que um homem não pode dominar e impor sua vontade sobre os demais. E são os institutos legais aquilo que, garantindo a atribuição de direitos iguais a todos, pode impedir esse domínio. Isso não significa que a coerção não seja o último recurso da lei, que a violência tenha de ser suprimida antes de se formar um espaço público, mas sim que a esfera pública só é legítima quando está organizada de forma a conter e limitar a dominação, isto é, com a primazia do poder sobre a coerção.

Ainda que direitos negativos (isto é, direitos que garantem um governo limitado e significam uma salvaguarda contra ele) não sejam equivalentes à participação política, eles sem dúvida oferecem um grau de liberdade e uma possibilidade de mudança, uma possibilidade de ação. Em Sobre a Revolução, Arendt é enfática ao defender os ganhos políticos advindos do governo limitado e dos direitos civis: "não podemos de maneira alguma esquecer (...) que a distância entre a tirania e o governo constitucional limitado é tão grande ou talvez ainda maior do que a distância entre o governo limitado e a liberdade". (ARENDT, 2011, p. 278, ver também p. 190-1). Se, em determinada comunidade, ainda há muito pelo que se conquistar em termos de estruturação de uma esfera pública participativa, isso não significa que essa conquista não se dará em conjunto com - e a partir de - esses direitos negativos; em outras palavras, são esses direitos que permitem discutir, pensar e organizar uma nova estrutura, porque, ainda que restritos, a ação e o discurso ainda são possíveis nessa comunidade.

Direitos civis, a própria noção de personalidade jurídica, a estrutura legal que organiza as relações humanas, protegendo os homens uns dos outros, mas também conectando-os, essas são todas formas de se lidar com a questão da violência e da dominação. Para Arendt, só existe Política em conjunto com o Direito, porque sem institutos legais que assegurem a igualdade entre os homens, não é possível haver relações livres, mas apenas tirania e submissão. 
A distinção analítica entre poder e violência, portanto, não se traduz em uma noção de política purificada e reduzida à práxis comunicativa. Habermas, ao criticar o pensamento arendtiano em seu artigo "O Conceito de Poder em Hannah Arendt", afirma que a política não pode ser identificada com a práxis daqueles que discursam em conjunto visando a agir comunitariamente como Arendt teria feito (HABERMAS, 1980), e embora ele esteja certo em afirmar que a política não é apenas a geração de legitimidade, a atribuição dessa noção ao pensamento político de Arendt é reducionista. É verdade que o pensamento arendtiano não sistematiza as instituições que garantem a liberdade, ou se ocupa da aplicação dos princípios e normas que estabelece, mas isso não significa, por outro lado, que Arendt mantenha uma noção de política que prescinde da aplicação ou mesmo dessas instituições. O pensamento arendtiano estabelece normas e critérios segundo os quais podemos avaliar comunidades, práticas e instituições políticas reais, e seu conceito de poder é um conceito normativo porque, antes de mais nada, ele é um instrumento teórico que permite lidar com as relações políticas reais e a avaliá-las em sua legitimidade. Igualdade política, liberdade, espaço público, pluralidade, nenhum desses conceitos tem algum sentido sem um sistema que os ampare, o qual Arendt nunca pretendeu eliminar, definindo o governo como "essencialmente poder organizado e institucionalizado" (ARENDT, 2006, p. 129).

Sua quebra com a noção tradicional de poder significa uma tomada de posição crítica em relação à tradição do pensamento político. A política não é equivalente à dominação de um grupo por outro, a política também não se reduz às relações econômicas, nem à administração da sociedade de massa. A política, segundo Arendt, é a vida em conjunto, são as relações entre os homens, é a convivência humana que não é natural - isto é, que é regida pelo princípio da liberdade e por isso é construída pelos homens conjuntamente, em suas relações mútuas -, e o conceito de poder de Arendt é um instrumento analítico que permite lidar teoricamente com essas relações. O conceito de poder arendtiano ilumina a possibilidade de uma práxis comunicativa que serve como medida para a crítica da realidade.

Em suas obras, Arendt foca-se, no mais das vezes, nos problemas gerados quando as instituições, organizações e relações se afastam dessa base que lhes legitima, apontando os momentos em que o poder é esvaziado. Exemplo disso é a reflexão arendtiana sobre o movimento operário. No capítulo sobre a ação, em $A$ Condição Humana, Arendt elogia os ganhos políticos desse movimento e afirma que o movimento "escreveu um dos mais gloriosos capítulos da história recente, e talvez o mais promissor" ${ }^{18}$. Esses ganhos estão no fato de que, em virtude de lutas e reivindicações, o trabalhador moderno passou a ser 
admitido na esfera pública, se emancipou completamente como cidadão e, devido a sua organização, desenvolveu e propôs idéias próprias quanto às possibilidades do governo democrático sob condições modernas - o que significa que um novo segmento da população pôde aparecer em público, criando espaços em que os homens agiam a falavam enquanto homens $\mathrm{O}$ fato de que o movimento operário nunca foi exclusivamente um movimento político e que suas reivindicações políticas acompanharam inúmeras reivindicações econômicas não é apontado por Arendt como um problema, porque o que importa é a criação e a manutenção de espaços comunicativos que emprestam legitimidade às reivindicações e às conquistas (normalmente na forma de direitos) desse movimento. O problema surge no momento em que o movimento se enrijece em torno de programas e ideologias oficiais, porque quanto mais toma a forma de um partido político, menos espaço ele possui para a ação e o discurso e, conseqüentemente, para a política. É aqui que reside a crítica arendtiana. Embora o movimento operário tenha mantido sua força enquanto um grupo de pressão, e mesmo que tenha seguido tendo sucesso em outras reivindicações, sua legitimidade advinda de uma prática comunicativa diminuiu cada vez mais.

Quando aponta essa trajetória, Arendt joga luz na dinâmica do movimento não para negar seus ganhos (tanto econômicos, quanto políticos e jurídicos), mas sim para trazer à tona dilemas da política contemporânea sobre os quais é necessário refletir. As vantagens da institucionalização dos movimentos sociais são acompanhadas de perdas de espaço para práticas comunicativas porque a lógica da disputa partidária é diferente da lógica comunicativa. Ao mostrar isso, quer dizer, ao evidenciar os dilemas das organizações contemporâneas, Arendt não está defendendo que a política deve se restringir à geração de legitimidade, mas explicita uma tensão fundamental com o qual a política contemporânea tem de lidar. Não oferecer uma solução a esse dilema não diminui o potencial crítico de sua teoria, que aponta na realidade os problemas que precisam ser enfrentados. Os conceitos de poder e violência servem, portanto, como padrões de acordo com os quais é possível refletir acerca da maior ou menor liberdade de espaços determinados. Seu pensamento é crítico porque oferece essa capacidade de julgar e avaliar a realidade, não de acordo com idéias utópicas, mas com base em princípios e normas que buscam respostas e se relacionam a inquietações provindas de problemas bastante contemporâneos.

A noção de política arendtiana não ignora o fenômeno da violência. A existência humana está sempre permeada de violência, que o pensamento arendtiano não ignora ingenuamente; como visto acima, a violência foi um dos principais fenômenos do século XX, 
disseminada desde o totalitarismo à Guerra Fria, desde a luta por cidadania à luta por igualdade e direitos civis, porém Arendt não deixa de mostrar que, em meio a tudo isso, existe a possibilidade de reflexão e crítica da realidade, e de criação e organização de espaços de liberdade.

Assim, a filosofia de Hannah Arendt nos mostra que o Direito cria canais artificiais entre os homens que fazem com que possam tratar-se mutuamente como iguais, e isso, por sua vez, visa a controlar a violência. Ela mostra também que, embora o Direito relacione-se diretamente à prática política, o limite legal não é suficiente para a constituição e manutenção de uma comunidade política ${ }^{19}$ - para isso, é preciso poder. O poder é gerado comunicativamente. Isso significa que ele se baseia, em última instância, na capacidade humana de julgar e na mentalidade alargada, porque é o alargamento da mentalidade que permite que se saia de si mesmo para encontrar e reconhecer o outro. É na prática da reversibilidade de perspectivas, na tentativa de cortejar a concordância do outro, na necessidade de tornar públicas e comunicáveis suas razões que os homens se relacionam com o outro de forma equitativa, pois assim se reconhece o outro como alguém cuja opinião merece respeito. O contrário disso, como visto, é a violência. A prática da mentalidade alargada permeia as relações humanas com respeito e tolerância pelo diferente, tornando-as mais aptas e dispostas a lidar com os conflitos no espaço público de forma democrática e não através de dominação ou subjugação, e é assim que se vai além da simples igualdade formal imposta pelos limites legais e se gera legitimidade - para o Direito e para o corpo político. Nesse sentido, o Direito e a mentalidade alargada aparecem, na filosofia arendtiana, como duas formas diferentes mas complementares de se lidar com a violência na organização do espaço público, e apontam para uma noção de política baseada em uma cultura democrática de solidariedade e igualdade fundamentais. 


\section{Notas:}

${ }^{1}$ Doutora em Filosofia pela Universidade Estadual de Campinas (UNICAMP). Realiza estágio pos-doutoral na UNICAMP, Campinas, S.P., Brasil, com financiamento PNPD/CAPES. e-mail: romolobrito@gmail.com

${ }^{2}$ É bastante significativo que Arendt traga para exemplificar a decadência da verdade racional e a valorização da opinião os pensamentos de um filósofo e de um político, revelando que, embora não se comprometesse com uma perspectiva filosófica naquele momento, o estatuto filosófico tanto da opinião, quanto da razão também direcionam suas reflexões, como veremos a seguir.

${ }^{3}$ Irei me restringir, nesse momento, a analisar a obra Lições de Filosofia Política de Kant visando a compreender o papel que o conceito de mentalidade alargada tem na filosofia política de Hannah Arendt. Acredito que a mentalidade alargada possa ser compreendida como um processo que fundamenta e legitima o juízo e a opinião que formam o corpo político, o que portanto legitima também esse corpo político. Por falta de espaço, entretanto, não irei cotejar esse conceito arendtiano com texto kantiano, o que espero poder fazer no futuro.

${ }^{4}$ Arendt afirma que se apoiará na primeira parte da Crítica do Juízo de Kant, "Crítica do Juízo Estético", que, segundo ela, contém o aspecto mais original da filosofia política kantiana, por conter "uma analítica do belo, basicamente do ponto de vista do espectador ajuizante" (ARENDT, 1979, p. 273). Essa vinculação entre juízo e espectador significa, para Beiner, em seu ensaio interpretativo sobre Lições de Filosofia Política de Kant, uma extensão da definição arendtiana de política como virtuosismo ou performance (BEINER, 1989, p. 104). Entretanto, discordo da ênfase que essa leitura de Beiner coloca no juízo como algo que fica de fora do espaço público, como veremos a seguir.

${ }^{5}$ Nas palavras de Arendt: "Para nós, a aparência - aquilo que é visto e ouvido pelos outros e por nós mesmos constitui a realidade." (ARENDT, 2003, p. 59)

${ }^{6}$ É nesse sentido que Arendt cita a frase de Madison, em diferentes textos, afirmando que "todo governo assentase na opinião". Em outro momento, Arendt diretamente menciona "a força da opinião, isto é, o poder do governo (...)" (ARENDT, 2006, p. 121)

${ }^{7}$ Em "Verdade e Política", Arendt descreve os mesmos passos da formação do juízo como passos para formar uma opinião: "Formo uma opinião considerando um dado tema de diferentes pontos de vista, fazendo presentes em minha mente as posições dos que estão ausentes; isto é, eu os represento. (...) É essa capacidade de uma "mentalidade alargada" que habilita os homens a julgarem (...)". (ARENDT, 1979, p. 299.). A opinião é o pensamento que fica após o julgamento e a tomada de decisão de um indivíduo. Nesse mesmo sentido, Ronald Beiner afirma: "Fica claro que o julgamento e a opinião estão inextricavelmente relacionados como as principais faculdades da razão política. A intenção de Arendt é bastante óbvia: concentrar o foco na faculdade do julgamento é resgatar a opinião do descrédito em que ela caiu desde Platão." (BEINER, 1989, p. 108, tradução minha).

${ }^{8}$ V. Cap. 5 de $A$ Condição Humana (em especial o item 32, intitulado "A Ação como Processo") e "O Conceito de História", em Entre o Passado e o Futuro, entre outros.

${ }^{9}$ Acredito que a leitura de outros textos arendtianos, em conjunto com A Condição Humana, oferece apoio para a compreensão da política na filosofia de Hannah Arendt como um processo democrático contínuo de formação discursiva de opinião e institucionalização do espaço público moderno que é criticamente útil para as sociedade atuais, o que uma leitura mais restrita à obra $A$ Condição Humana não favorece.

${ }^{10}$ Essa metáfora também é retomada na obra Sobre a Revolução. (ARENDT, 2011, p. 148).

${ }^{11}$ Em A Condição Humana, podemos ver as implicações dessa noção.

${ }^{12}$ Essa é uma formulação que também é analisada no artigo "Da Violência".

${ }^{13}$ No debate "Legitimacy of Violence", Arendt, de forma bastante sucinta, marca essa diferença ao observar que: "O oposto da liberdade é ou a necessidade ou a opressão. Nós somos confrontados com a necessidade sempre que a sobrevivência física está em jogo. Apenas quando essa sobrevivência está garantida é que os homens 
podem começar a pensar sobre a luta contra a opressão. (...) Então sempre que há fome extrema, não pode haver liberdade, e nenhuma educação aristotélica - quer acreditemos nela ou não - ou nenhum Tomás de Aquino podem ajudar." (ARENDT, 2010b, tradução minha).

${ }^{14}$ Vale repetir as palavras de Arendt: "Nem a violência nem o poder são fenômenos naturais, isto é, manifestações do processo vital; pertencem ao domínio político dos assuntos humanos cuja qualidade essencialmente humana é garantida pela faculdade do homem de agir, isto é, pela sua capacidade de principiar algo novo." (ARENDT, 2006, p. 152).

${ }^{15}$ Segundo Arendt, a noção tradicional de que a política se restringe à dominação também pode ser percebida na clássica distinção entre as diferentes formas de governo.

${ }^{16}$ Vale enfatizar novamente que dependendo do âmbito em que os fenômenos da necessidade ou da violência aparecem - como no âmbito do trabalho ou da fabricação, ou mesmo a coerção legitimada por uma estrutura mais ampla fundamentada no poder definido como agir em conjunto -, eles não constituem um problema para Arendt, sendo parte da existência humana.

${ }^{17}$ Nesse sentido, vale enfatizar as palavras de Benhabib sobre a relação entre mentalidade alargada e juízo e instituições do espaço público-político regidas por princípios de liberdade e democracia: “A mentalidade alargada, que moralmente nos obriga a pensar do ponto de vista de todos os outros, politicamente requer a criação de instituições e práticas por meio das quais a voz e a perspectiva dos outros, freqüentemente desconhecidas por nós, podem ser expressadas por seu direito próprio." E ela continua, a respeito do papel político que a mentalidade alargada tem na filosofia arendtiana: "Um dos maiores enganos da teoria moral kantiana é assumir que os princípios da mentalidade alargada podem ser concebidos via o experimento de pensamento isolado de um pensador. Esses experimentos de pensamento solitários freqüentemente substituem o ponto de vista de todos pelo ponto de vista de uma parte privilegiada. De fato, dificilmente isso pode ser diferente. Pois 'pensar do ponto de vista de todos os outros', na filosofia moral kantiana, é equivalente a pensar do ponto de vista de apenas um, que é igual a todos os outros em virtude de ser um agente autônomo e puramente racional. Uma vez que rejeitamos a metafísica de dois-mundos da teoria kantiana, como também a definição de nossas identidades morais em termos puramente racionais, e prosseguimos para as perspectivas da natalidade, pluralidade e narratividade da ação, temos de perceber que 'pensar do ponto de vista de todos os outros' implica compartilhar uma certa cultura pública em que todos os outros podem articular, realmente, o que eles pensam e quais as suas perspectivas. $\mathrm{O}$ cultivo da imaginação moral de uma pessoa prospera nessa cultura em que a perspectiva centrada em si mesmo do indivíduo é constantemente desafiada pela multiplicidade e diversidade de perspectivas que constituem a vida pública. Nesse sentido, Hannah Arendt estava correta ao sustentar que o juízo é a mais política de todas as faculdades humanas, pois ele leva à recuperação de uma das qualidades do mundo público em que a ação acontece, isto é, a recuperação da qualidade de ser constituído por perspectivas." (BENHABIB, 1992, p. 140-1, tradução e ênfase minhas)

${ }^{18}$ Arendt aponta dilemas semelhantes em Sobre a Revolução, quando defende que direitos civis são condições necessárias para a liberdade mas não são suficientes, sendo necessários também direitos políticos, ou que a luta pela libertação não significa o mesmo que a luta pela liberdade. Esses são momentos de crítica em que Arendt questiona a realidade de acordo com seu conceito normativo de poder e, segundo as noções de dominação e liberdade, aponta um déficit de liberdade. Ela não defende que apenas direitos políticos são importantes e que é possível dispensar os direitos civis, da mesma forma que Arendt não crê que possa haver liberdade sem libertação; seu objetivo é demonstrar um déficit de liberdade e poder que não pode ser preenchido por outros ganhos, ainda que esses ganhos sejam também essenciais para a vida humana.

${ }^{19}$ Em Origens do Totalitarismo, Arendt analisa as equivocidades da emancipação judaica e critica os judeus por acreditarem que a noção de igualdade legal seria o suficiente para protegê-los eternamente dentro de um corpo político, mesmo que essa estrutura jurídica tivesse se dissociado das práticas políticas da comunidade de que faziam parte. Ela afirma: "Precisamente por haverem representado [os judeus] papel tão insignificante no desenvolvimento político dos países em que viviam, a igualdade jurídica transformou-se, para eles, num fetiche, parecendo-lhes constituir a base indiscutível de sua eterna segurança.” (ARENDT, 1989b, p. 140.) 


\section{Referências bibliográficas:}

ARENDT, H. Entre o passado e o futuro. Tradução de Mauro W. Barbosa. São Paulo: Ed. Perspectiva, 1979.

. Lectures on Kant's Political Philosophy. Chicago: The University of Chicago Press, 1989a.

. Origens do Totalitarismo. Tradução de Roberto Raposo. São Paulo: Companhia das Letras, 1989b.

. Essays in Understanding. New York: Schocken Books, 1994a.

. Lições de Filosofia Política de Kant. Tradução de André Duarte de Macedo. 2. ed. Rio de Janeiro: Relume Dumará, 1994b.

. "Introduction". In: J. Glenn GRAY. The Warriors. Reflections of Men in Battle. p. XXI. Lincoln and London: University of Nebraska Press: 1998.

- A Vida do Espírito. Tradução de Antônio Abranches e Helena Martins. Rio de Janeiro: Relume Dumará, 2002.

A Condição Humana. Tradução de Roberto Raposo. 10 ed. Rio de Janeiro: Forense Universitária, 2003.

. Crises da República. Tradução de José Volkmann. São Paulo: Perspectiva, 2006.

. "Some Questions on Moral Philosophy". Em: The Hannah Arendt Papers at the Library of Congress. (http://memory.loc.gov/ammem/arendthtml/mharendtFolderP04.html) Acessado em 07 de setembro de 2010a).

. "Legitimacy of Violence". Em: The Hannah Arendt Papers at the Library of Congress (http://memory.loc.gov/ammem/arendthtml/mharendtFolderP05.html) Acessado em 16 de novembro de 2010b).

. Sobre a Revolução. Tradução de Denise Bottman. São Paulo: Companhia das Letras, 2011.

BEINER, R. “Arendt on Judging”. Em: ARENDT, Hannah. Lectures on Kant's Political Philosophy. Chicago: The University of Chicago Press, 1989.

BENHABIB, S. Situating the Self. New York, Routledge, 1992.

. The reluctant modernism of Hannah Arendt. New York. Sage Publications. 1996. 
OWENS, P. Between War and Politics. International Relations and the Thought of Hannah Arendt. Oxford: Oxford University Press, 2007.

HABERMAS, J. “O Conceito de Poder em Hannah Arendt”. Em. FREITAG, B.; ROUANET, S. P. (orgs.). Habermas: sociologia. São Paulo, Ática, 1980. 